\title{
ANALISIS IMPLEMENTASI MODEL PEMBELAJARAN BLENDED LEARNING UNTUK MENINGKATKAN KEMANDIRIAN BELAJAR PADA TEMA MENUJU MASYARAKAT SEJAHTERA SISWA KELAS VI (STUDI KASUS DI SD NEGERI 1 KEMUJAN PADA ERA COVID-19 TAHUN AJARAN 2020/ 2021)
}

\author{
Apriliani Indah Sari ${ }^{1}$, Rokhmaniyah $^{2}$, Tri Saptuti Susiani ${ }^{3}$
}

Universitas Sebelas Maret

indahsariapriliani@student.uns.ac.id

\section{Article History}

accepted 30/8/2021

\begin{abstract}
The study aimed to describe the implementation of blended learning model to improve independent learning in theme 'Towards a Prosperous Community' for sixth grade students of SD Negeri 1 Kemujan in the Covid-19 era. It was qualitative approach with a case study research method. The results showed that learning planning was classified as good, which included making learning schedules, compiling blended learning lesson plans, choosing the type of blended learning model, preparing materials, tools / media, face-to-face and online learning resources, and implementing the Covid-19 health protocol during learning. face to face. The implementation of learning is quite sufficient, which is done face-to-face and online with activities seeking of information, acquisition of information, and synthesizing of knowledge. The evaluation of blended learning has provided good students with independent learning such as students having independent learning initiatives to find out more about the material presented by the teacher, responsibility for doing assignments, discipline in obeying the rules in school, confident in expressing opinions, and have the motivation to achieve good learning outcomes. The conclusion of this study is that blended learning model to improve learning independence has been carried out well and the obstacles experienced have been overcome by the teacher.
\end{abstract}

Keywords: implementation, blended learning, independent learning, Covid-19

\begin{abstract}
Abstrak
Penelitian ini bertujuan untuk mendeskripsikan implementasi model pembelajaran blended learning untuk meningkatkan kemandirian belajar siswa kelas VI di SD Negeri 1 Kemujan pada era Covid-19. Penelitian ini menggunakan pendekatan kualitatif dengan metode studi kasus. Hasil penelitian menunjukkan bahwa perencanaan pembelajaran tergolong baik yang meliputi pembuatan jadwal pembelajaran, menyusun RPP blended learning, pemilihan jenis model pembelajaran blended learning, menyiapkan bahan, alat/media, dan sumber belajar tatap muka dan online, dan penerapan protokol kesehatan Covid-19 saat pembelajaran tatap muka. Pelaksanaan pembelajaran tergolong cukup yaitu dilakukan secara tatap muka dan online dengan kegiatan seeking of information, acquisition of information, dan synthesizing of knowledge. Evaluasi pembelajaran blended learning telah memberikan kemandirian belajar pada siswa yang baik seperti siswa memiliki inisiatif belajar mandiri untuk mengetahui lebih jauh materi yang disampaikan oleh guru, tanggung jawab dalam mengerjakan tugas, disiplin dalam menaati peraturan yang ada di sekolah, percaya diri dalam mengungkapkan pendapat, dan memiliki motivasi untuk mencapai hasil belajar yang baik. Kesimpulan penelitian ini adalah model pembelajaran blended learning untuk meningkatkan kemandirian belajar telah terlaksana dengan baik dan kendala yang dialami telah diatasi oleh guru.
\end{abstract}

Kata kunci : implementasi, blended learning, kemandirian belajar, Covid-19 


\section{PENDAHULUAN}

Pada masa ini keadaan masyarakat dunia sedang dilanda oleh adanya pandemi Coronavirus Disease 2019 atau sering kita sebut sebagai Covid-19. Handayani, dkk. (2020: 108) menyatakan bahwa virus ini merupakan penyakit baru yang sebelumnya hanya dapat menular ke hewan saja, tetapi dengan cepatnya dapat menular dan masuk ke tubuh manusia dengan kasat mata serta dapat mengakibatkan kematian. Oleh karena itu, World Health Organization (WHO) menetapkan bahwa kondisi dunia dan kesehatan masyarakat dalam keadaan sangat darurat (Dewi, 2020: $56)$.

Pandemi Covid-19 telah berdampak pada semua aspek kehidupan masyarakat termasuk dalam bidang pendidikan. Berdasarkan Surat Edaran Nomor 4 Tahun 2020 tentang Pelaksanaan Kebijakan Pendidikan dalam Masa Darurat Penyebaran Covid-19 menyatakan bahwa proses pembelajaran dilaksanakan dari rumah melalui pembelajaran daring atau online guna mencegah penyebaran coronavirus disease (Mendikbud, 2020). Adanya kebijakan tersebut memunculkan perubahan pada pola pembelajaran yang semula dilakukan secara tatap muka menjadi pembelajaran daring. Menurut UU RI Nomor 20 Tahun 2003 pasal 1 ayat 15 menyatakan bahwa pendidikan jarak jauh adalah pendidikan yang peserta didik dengan pendidik terpisah dan pembelajarannya menggunakan berbagai sumber belajar dari internet atau media lain. Pembelajaran daring pada masa Covid-19 memerlukan internet dan alat bantu berupa smartphone untuk mengakses internet serta e-learning yang digunakan untuk menunjang kegiatan pembelajaran. Pembelajaran di sekolah dasar yang dilakukan secara daring memang dapat membuat siswa lebih mandiri dan bisa belajar dimanapun dan kapanpun. Namun, pada kenyataannya pembelajaran daring tidak sepenuhnya dapat membuat anak belajar mandiri. Beberapa siswa yang mengalami kesulitan belajar dalam mengikuti pembelajaran daring seperti tidak semua siswa memegang dan memiliki HP pribadi, terkadang jaringan internet yang susah sinyal, dan siswa tidak bisa memahami materi apabila hanya diberikan tugas tanpa penjelasan materi dari guru. Hal tersebut senada dengan pendapat Handayani, dkk (2020: 107) yang menyatakan bahwa anak memerlukan tambahan kuota internet untuk pembelajaran daring dan orang tua tidak dapat selalu membimbing anak belajar dari rumah karena keterbatasan pengetahuan dan waktu dalam mendampingi anak belajar.

Kusumaningrum, dkk (2020: 144) menyatakan orang tua memiliki peranan penting dalam perkembangan kognitif, afektif, dan psikomotorik siswa sekolah dasar dalam pembelajaran terlebih dalam pembelajaran daring. Oleh karena itu, pembelajaran daring khususnya bagi siswa sekolah dasar masih perlu bimbingan dan pendidikan yang lebih dari guru maupun orang tua. Di dalam pembelajaran daring guru dapat membimbing siswa dengan memanfaatkan media online untuk menyampaikan materi secara online melalui video pembelajaran, berdiskusi online di chatroom, mengarahkan siswa unuk belajar mandiri di rumah, dan memberikan tugas. Sedangkan orang tua membimbing anak di rumah dengan cara memberikan pengawasan dan pendampingan belajar anak di rumah.

Han, Wang, dan Jiang (2019: 99-113) mengungkapkan bahwa blended learning is a combination of face to face and online mediated instruction. Menurut Yuliati \& Saputra (2020: 144) model pembelajaran blended learning dapat diterapkan untuk meningkatkan kemandirian belajar terutama pada masa Covid-19. Pembelajaran blended learning di kelas VI merupakan strategi bauran untuk menyampaikan materi secara tepat selama proses pembelajaran. Pola pembelajaran blended learning yang disajikan secara tatap muka dan online dapat melatih siswa untuk belajar secara mandiri. Peserta didik dapat mencari pengetahuan dan informasi secara mandiri 
melalui internet yang dapat diakses tanpa adanya batasan ruang dan waktu. Selain itu, dengan pembelajaran blended ini siswa dapat mendalami materi dengan melakukan kolaborasi bersama peserta didik lain dalam memahami materi saat tatap muka di kelas. Dengan model pembelajaran blended learning, maka siswa dapat mengembangkan kemampuan yang dimilikinya dan dapat mengakses berbagai informasi dari berbagai sumber untuk meningkatkan kemandirian belajar. Kemandirian belajar merupakan kemampuan yang harus dimiliki setiap peserta didik dalam mengikuti pembelajaran. Kemandirian yang dimaksud dalam proses pembelajaran yaitu peserta didik secara aktif menggunakan kemampuannya untuk belajar. Hal ini senada dengan pendapat Hamka dan Vilmala (2019: 148) bahwa kemandirian belajar merupakan inisiatif diri untuk belajar dan bertanggung jawab dalam segala hal.

Berdasarkan hasil observasi awal dan wawancara dengan guru kelas VI SD Negeri 1 Kemujan pada tanggal 12 Oktober 2020 diperoleh bahwa pembelajaran blended learning mulai dilaksanakan pada tahun ajaran 2020/2021 pada semester ganjil dan genap. Pembelajaran blended learning guru lakukan setelah melalui masa transisi akibat adanya pandemi Covid-19 yang telah mengubah pola pembelajaran dari tatap muka menjadi pembelajaran daring. Dari masa transisi tersebut ternyata ditemukan masalah seperti, terdapat siswa yang tidak memiliki smartphone, ketersediaan kuota, jaringan internet, kemampuan siswa dalam memahami materi yang tidak bisa dipantau secara langsung, dan orang tua yang tidak bisa memantau anak saat belajar di rumah. Oleh karena itu, pihak sekolah memutuskan untuk melakukan pembelajaran tatap muka dan pembelajaran online (blended learning) sesuai protokol kesehatan dan memperhatikan kondisi wilayah yang penyebaran Covid-19 masuk pada zona hijau. Peneliti mempertimbangkan pemilihan di kelas VI karena melihat dari pengalaman guru dalam melaksanakan pembelajaran model blended learning dengan tujuan agar siswa dapat mengembangkan kemandirian belajar dan kemampuan siswa dalam mencari informasi atau memahami materi secara mandiri. Model pembelajaran blended learning bisa menjadi alternatif yang digunakan untuk pembelajaran di masa pandemi Covid-19, karena media dan sumber belajar yang disajikan oleh blended learning telah menjadi perpanjangan ruang kelas bagi siswa untuk diakses tanpa ada batasan waktu dan tempat. Tujuan penelitian ini yakni untuk mendeskripsikan implementasi model pembelajaran blended learning untuk meningkatkan kemandirian belajar siswa kelas VI di SD Negeri 1 Kemujan pada Era Covid-19.

\section{METODE}

Penelitian ini dilaksanakan di kelas VI SD Negeri 1 Kemujan. Penelitian menggunakan pendekatan kualitatif dengan metode studi kasus. Subjek penelitian ini yaitu guru dan siswa kelas VI yang berjumlah 29 siswa dengan laki-laki sebanyak 16 siswa dan perempuan sebanyak 13 siswa. Sumber data penelitian ini yakni kepala sekolah, guru, siswa, dan orang tua siswa kelas VI. Teknik pengumpulan data menggunakan teknik observasi, wawancara, dokumen. Adapun validitas data dalam penelitian ini dilakukan dengan triangulasi sumber dan teknik. Analisis data menggunakan model analisis data kualitatif menurut Miles dan Huberman yang meliputi reduksi data, penyajian data, dan verifikasi untuk mendeskripsikan implementasi model pembelajaran blended learning untuk meningkatkan kemandirian belajar siswa kelas VI di SD Negeri 1 Kemujan pada Era Covid-19.

HASIL DAN PEMBAHASAN

1. Implementasi Model Pembelajaran Blended Learning untuk Meningkatkan Kemandirian Belajar pada Tema Menuju Masyarakat Sejahtera Siswa Kelas VI di SD Negeri 1 Kemujan pada Era Covid-19 a. Perencanaan Pembelajaran Blended Learning 
Berdasarkan hasil observasi dan wawancara didapatkan data bahwa perencanaan pembelajaran blended learning yang disusun guru kelas VI $88,2 \%$, perencanaan pembelajaran blended learning tergolong baik. RPP yang disusun guru sudah sesuai dengan SE Mendikbud No 14 Tahun 2019. Perencanaan pembelajaran blended learning dirancang untuk meningkatkan kemandirian belajar siswa pada era Covid-19. Oleh karena itu, pembelajaran di kelas VI juga disesuaikan dengan kondisi yang masih pandemi yang tertuang dalam Surat Keputusan Bersama 4 Menteri tentang Penyelenggaran Semester Genap Tahun 2020-2021 di Masa Pandemi. Hal ini sependapat dengan hasil wawancara dengan guru kelas VI bahwa dalam merencanakan model pembelajaran blended learning disesuaikan dengan kemampuan siswa dan memperhatikan kondisi yang masih dalam pandemi.

Berdasarkan hasil observasi dan wawancara dalam merancang pembelajaran blended learning guru telah memenuhi indikator yang telah ditetapkan. Perencanaan pembelajaran meliputi: a) pembuatan jadwal pembelajaran; b) menentukan jenis model blended learning; c) menyusun RPP blended learning; d) menyiapkan alat, bahan/media, dan sumber belajar tatap muka dan daring; e) penerapan protokol kesehatan saat pembelajaran tatap muka.

Berdasarkan hasil observasi, wawancara, dan studi dokumen didapat bahwa pembuatan jadwal pembelajaran tatap muka dan daring ditentukan oleh guru. Jadwal pembelajaran tatap muka dilakukan 2 kali dalam seminggu yaitu hari Kamis dan Sabtu pukul 07.30 sampai 12.35 (khusus saat pembelajaran tatap muka kelas dibagi dalam dua waktu kelompok belajar) dengan pembagian waktu kelompok 1 pukul 07.30-09.50 dan kelompok 2 pukul 10.15-12.35 tanpa istirahat. Sedangkan pembelajaran daring secara mandiri siswa lakukan di rumah melalui LMS (Whatsaap dan Google Classroom). Hal ini sejalan dengan pendapat Indriani, dkk (2018:130-139) yang menyatakan bahwa pembuatan jadwal pembelajaran disusun oleh koordinator pendidikan jarak jauh atau pendidik dalam sekolah.

Berdasarkan hasil observasi dan wawancara dalam menentukan jenis model blended learning guru tidak mencantumkan jenis model blended learning dalam RPP yang digunakan, tetapi dalam melakukan pembelajaran guru mengombinasikan pembelajaran tatap muka, online, dan mandiri (rotation model) yang disesuikan dengan jadwal pembelajaran yang dapat dilakukan di kelas dan di rumah. Hal ini didukung juga dengan hasil analisis dokumen RPP yang disusun guru menunjukkan bahwa dalam RPP tidak terdapat jenis model blended learning yang digunakan, akan tetapi RPP yang disusun guru ada dua jenis RPP yaitu daring dan luring.

Berdasarkan hasil analisis dokumen menunjukkan bahwa susunan RPP blended learning yang guru gunakan berpedoman pada kurikulum 2013, kurikulum pada kondisi khusus, dan silabus. Susunan komponen RPP yang dibuat guru meliputi: 1) identitas RPP; 2) perumusan tujuan pembelajaran; 3) menentukan kegiatan pembelajaran; 4) alat dan bahan; 5) penilaian pembelajaran. Hal ini sesuai dengan SE No. 14 Tahun 2019 tentang Penyederhanaan Rencana Pelaksanaan Pembelajaran yang yang menyatakan bahwa penulisan RPP dilakukan dengan efisien dan efektif sehingga guru memiliki lebih banyak waktu untuk mempersiapkan dan mengevaluasi proses pembelajaran itu sendiri. Senada juga dengan pendapat Miyarso (2019: 83-88) yang menyatakan bahwa dalam menyusun RPP blended learning yang diperlukan yaitu RPP pembelajaran konvensional, karena dengan RPP konvesional pendidik dapat mengembangkan komponen-komponen yang harus 
ada pada RPP blended learning seperti identitas RPP, rumusan tujuan pembelajaran, kegiatan pembelajaran dan metode penilaian.

Berdasarkan hasil wawancara menunjukkan dengan guru kelas $\mathrm{VI}$ dalam menyiapkan bahan, alat/media, dan sumber belajar yang digunakan guru kelas VI di SD Negeri 1 Kemujan selama pembelajaran blended learning guru menentukan LMS yang digunakan untuk pembelajaran online seperti zoomeeting, google classroom, LMS SCI media, dan membuat grup whatsapp. Selain itu guru juga memanfaatkan sumber belajar online dan offline seperti siaran TV, video pembelajaran, internet, dan lingkungan sekitar. Hal ini sejalan dengan pendapat Miyarso (2019: 83-88) dalam pembelajaran blended learning pendidik dapat memanfaatkan LMS (Learning Management System) atau aplikasi lain yang dapat digunakan untuk menunjang pembelajaran online.

Berdasarkan hasil observasi dan wawancara menunjukkan penerapan protokol kesehatan saat pembelajaran tatap muka telah guru lakukan dengan berperilaku wajib $3 \mathrm{M}$ yaitu mencuci tangan, memakai masker, dan menjaga jarak. Hal ini sejalan dengan Surat Keputusan Bersama 4 Menteri tentang Penyelenggaraan Pembelajaran Semester Genap Tahun 2020-2021 di Masa Pandemi yang menyatakan sekolah yang siap melakukan tatap muka wajib melakukan: 1) setting kelas atau tempat duduk siswa harus jaga jarak minimal 1,5 meter dan jumlah maksimal peserta didik per ruang kelas khususnya siswa sekolah dasar dan menengah adalah 18 (dari standar 36 peserta didik); 2) jadwal pelajaran dilakukan dengan sistem bergiliran rombongan belajar (shifting) yang ditentukan satuan pendidikan masing-masing; 3) ketentuan yang paling penting yaitu peserta didik dan pendidik wajib berperilaku wajib $3 \mathrm{M}$ (menggunakan masker kain tiga lapis atau masker sekali pakai, mencuci tangan pakai sabun dengan air mengalir, dan menjaga jarak minimal 1,5 meter).

Berdasarkan uraian tentang perencanaan pembelajaran blended learning untuk meningkatkan kemandirian belajar siswa kelas VI di SD Negeri 1 Kemujan pada era Covid-19 sudah terlaksana dengan kategori baik. Perencanaan pembelajaran blended learning yang disusun guru kelas VI SD Negeri 1 Kemujan meliputi: 1) pembuatan jadwal pembelajaran; 2) menentukan jenis model pembelajaran blended learning; 3) menyusun RPP blended learning; 4) menyiapkan alat, bahan/media, dan sumber belajar tatap muka dan daring; 5) penerapan protokol kesehatan Covid-19 saat pembelajaran tatap muka.

\section{b. Pelaksanaan Pembelajaran Blended Learning}

Berdasarkan hasil observasi dan wawancara didapatkan data bahwa pelaksanaan pembelajaran blended learning $77,7 \%$ tergolong cukup. Pembelajaran dilaksanakan dengan dua pola yaitu tatap muka dan online. Pembelajaran tata muka dilakukan dua kali dalam seminggu yaitu hari Kamis dan Sabtu, sedangkan pembelajaran online menggunakan LMS/media whatsapp dan google classroom. Pembelajaran tatap muka digunakan guru untuk memberikan penguatan materi yang sudah siswa pelajari di rumah, sedangkan pada pembelajaran online siswa belajar secara mandiri dengan memanfaatkan sumber belajar yang sudah disedikan oleh guru. Siswa mencari informasi dan mengembangkan kemandirian dalam mempelajari materi yang disampaikan oleh guru melalui video pembelajaran maupun buku pendalaman materi yang sudah dibagikan ke siswa. Oleh karena itu, fungsi LMS dalam program PJJ di masa pandemi ini dapat dikatakan sebagai pelengkap dan media yang dapat membantu guru dan siswa untuk melakukan pembelajaran di masa pandemi. Kegiatan pembelajaran blended learning di kelas VI lebih banyak dilakukan secara online karena masih memperhatikan kondisi yang 
pandemi dan mengurangi pembelajaran tatap muka. Hal ini sejalan dengan pendapat Allen, et el (Husamah, 2014) dalam tabel propotion of content dilivered online, yang mengatakan bahwa sebuah pembelajaran dikatakan sebagai pembelajaran blended learning apabila penggunaan e-learning-nya antara $30-79 \%$.

Berdasarkan hasil observasi dan wawancara dalam melaksanakan langkah-langkah model pembelajaran blended learning guru dan telah memenuhi beberapa indikator yang telah ditetapkan. Langkah pembelajaran seeking of information menunjukkan $89,6 \%$. Guru selalu menjadi fasilisator untuk siswa dalam penyampaian materi. Saat pembelajaran online siswa secara mandiri mempelajari materi yang telah diberikan guru melalui video pembelajaran dan buku pendalaman materi yang dibagikan ke siswa. Hasil wawancara dengan semua siswa kelas VI juga menunjukkan bahwa guru selalu membagikan acuan materi dalam setiap pembelajaran. Siswa secara mandiri mempelajari materi yang sudah guru berikan melalui LMS media whatssapp dan beberapa sumber lain seperti buku dan video pembelajaran. Data wawancara dengan semua siswa kelas $\mathrm{VI}$ juga menunjukkan bahwa siswa mempelajari materi yang diberikan guru. Saat pembelajaran tatap muka siswa aktif tanya jawab dengan guru, namun saat pembelajaran online siswa belum sepenuhnya aktif dalam bertanya karena keadaan fasilitas pendukung pembelajaran online belum sepenuhnya terpenuhi dari masing-masing siswa. Selain itu, guru tidak selalu memberikan kesempatan pada siswa untuk tanya jawab melalui e-learning yang digunakan sehingga siswa juga belum menampakkan keaktifan secara tidak langsung. Hal ini sejalan dengan hasil wawancara guru yang memberikan pernyataan bahwa guru melakukan tanya jawab pada siswa saat pembelajaran tatap muka saja, sedangkan pembelajaran online digunakan untuk pembelajaran mandiri dan memberikan tugas. Saat di kelas guru dapat dengan mudah menjelaskan materi dan melakukan tanya jawab tentang materi yang sedang dipelajari dengan siswa dibandingkan secara online siswa belum menampakan keaktifannya secara tidak langsung.

Berdasarkan hasil observasi dan wawancara langkah pembelajaran acquisition of information atau mengolah informasi menunjukkan 88,4\% tergolong baik. Dalam langkah ini kegiatan yang guru lakukan yaitu membentuk kelompok diskusi saat pembelajaran tatap muka atau siswa dapat berdiskusi dengan anggota keluarga/orang tua saat pembelajaran online, guru dan orang tua membimbing siswa saat pembelajaran, dan siswa mengerjakan tugas secara mandiri di rumah. Data hasil wawancara semua siswa menunjukan bahwa guru melakukan diskusi saat pembelajaran tatap muka dan guru secara langsung membimbing siswa saat diskusi, sedangkan saat pembelajaran daring guru memberikan kebebasan kepada siswa untuk belajar dengan teman atau anggota keluarga untuk berdiskusi tentang materi yang dipelajari. Bimbingan saat pembelajaran secara online guru lakukan melalui group whatsapp. Guru dan orang tua saling bekerjasama dalam membimbing siswa supaya pembelajaran tetap berlangsung secara efektif dan efisien walaupun siswa belajar secara mandiri di rumah masing-masing. Hal ini sejalan dengan pendapat Kusumaningrum, dkk (2020: 144) yang menyatakan bahwa dalam pembelajaran daring, orang tua memiliki peran untuk membimbing sikap dan keterampilan serta prestasi siswa. Bentuk peran orang tua tersebut sebenarnya adalah bentuk peran guru di sekolah, seperti memberi motivasi dalam segala hal, menjadi teman bahagia untuk belajar, membantu dalam menyelesaikan masalah dan kesulitan yang dihadapi anak-anak saat belajar serta mengembangkan rasa percaya diri anak. 
Berdasarkan hasil observasi dan wawancara langkah pembelajaran synthesizing of knowledge atau menyimpulkan informasi menunjukkan data $75,8 \%$ atau kategori cukup. Dalam langkah ini siswa hanya mempresentasikan hasil diskusi dan menyimpulkan pembelajaran saat pembelajaran tatap muka saja. Guru belum konsisten dalam memberikan kesempatan pada siswa untuk menyimpulkan pembelajaran diakhir pelajaran karena kondisi yang masih pandemi dan waktu yang terbatas, sehingga saat pembelajaran tatap muka guru lebih mengutamakan pada penjelasan materi dan pemberian tugas pada siswa. Selain itu, disetiap akhir pembelajaran siswa selalu mengumpulkan tugas yang guru berikan. Tugas juga dapat dikumpulkan secara online melalui grup Whatsaap atau datang langsung ke sekolah.

Berdasarkan beberapa uraian di atas guru dan siswa kelas VI di SD Negeri 1 Kemujan telah melaksanakan langkah-langkah pembelajaran blended learning seeking of information, acquisition of information, dan synthesizing of knowledge dalam pembelajaran tatap muka maupun online dengan kategori cukup. Kegiatan pembelajaran yang sudah guru lakukan secara konsisten adalah seeking of information dan acquisition of information, sedangkan pada langkah synthesizing of knowledge dapat dikatakan cukup dalam pelaksanaan pembelajaran karena guru masih menyesuikan pada keadaan siswa, kondisi yang masih dalam pandemi, dan waktu.

\section{c. Evaluasi Pembelajaran Blended Learning}

Evaluasi pembelajaran dalam penelitian ini digunakan untuk mengetahui secara keseluruhan implementasi model pembelajaran untuk meningkatkan kemandirian belajar pada era Covid-19 kelas VI di SD Negeri 1 Kemujan. Berdasarkan hasil observasi yang menyatakan bahwa kemandirian belajar yang diimplementasikan melalui model pembelajaran blended learning di kelas VI menunjukkan data $86,8 \%$ tergolong baik. Siswa sudah memiliki inisiatif belajar mandiri untuk mendalami materi yang diberikan oleh guru, memiliki sikap tanggung jawab dalam mengerjakan tugas, mengatur segala pekerjaan dengan disiplin dalam hal menaati peraturan yang ada di sekolah, memiliki rasa percaya diri dalam hal bersemangat mengikuti diskusi dan percaya diri dalam menyampaikan pendapat, dan memiliki motivasi untuk mencapai tujuan dalam hal memiliki keinginan untuk mendapatkan hasil belajar yang baik. Hal ini sejalan dengan pendapat Hamka dan Vilmala (2019: 145-154) yang menyatakan bahwa pembelajaran blended learning efektif untuk peningkatan kemandirian belajar siswa karena dalam pembelajaran siswa dapat saling berdiskusi dan berbagi informasi selain itu materi ajar berupa media pembelajaran video yang menarik dan mudah dipahami oleh siswa. Hal ini sejalan juga dengan pendapat Budiyono (2020:12) yang menyatakan bahwa implementasi blended learning di masa pandemi Covid-19 memberikan kemudahan dan kenyamanan kepada guru dan siswa dalam kegiatan belajar mengajar.

2. Kendala Implementasi Model Pembelajaran Blended Learning untuk Meningkatkan Kemandirian Belajar pada Tema Menuju Masyarakat Sejahtera Siswa Kelas VI di SD Negeri 1 Kemujan pada Era Covid-19

Dalam mengimplementasikan model pembelajaran blended learning untuk meningkatkan kemandirian belajar siswa kelas VI di SD Negeri 1 Kemujan pada era Covid-19 telah guru lakukan dengan baik. Namun, dalam pelaksanaannya terdapat kendala dalam mengimplementasikan pembelajaran blended learning yaitu: a) keterbatasan perangkat pembelajaran siswa yang tidak dapat mendukung pembelajaran online; b) terbatasnya kuota dan jaringan internet saat pengumpulan tugas; c) keterbatasan orang tua dalam mendampingi dan mengawasi anak belajar saat di rumah. Hal ini sejalan dengan pendapat Budiyono (2020: 9-11) yang 
menyatakan bahwa kendala dalam implementasi blended learning di masa pandemi meliputi penggunaan teknologi secara online yang memerlukan koneksi jaringan ke internet dan kuota. Sehingga, tingkat penggunaaan kuota internet akan bertambah dan akan menambah beban pengeluaran orang tua. Selain itu, kebanyakan dari orang tua wali belum mahir dalam penggunaan teknologi atau media yang digunakan guru.

3. Upaya dalam Mengatasi Kendala Implementasi Model Pembelajaran Blended Learning untuk Meningkatkan Kemandirian Belajar pada Tema Menuju Masyarakat Sejahtera Siswa Kelas VI di SD Negeri 1 Kemujan pada Era Covid19

Dalam implementasi model pembelajaran blended learning untuk meningkatkan kemandirian belajar pada tema menuju masyarakat sejahtera di kelas VI pada pandemi Covid-19 guru sudah melakukan yang terbaik agar dapat mencapai tujuan dari pembelajaran. Upaya yang dilakukan guru dalam menangani kendala dalam mengimplementasikan pembelajaran blended learning untuk meningkatkan kemandirian belajar pada era Covid-19 meliputi: a) penggunaan media pembelajaran online yang mudah dan disesuaikan dengan keadaan siswa; b) pengumpulan tugas yang dapat dikumpulkan secara langsung di sekolah; c) bekerjasama dengan orang tua untuk mendampingi dan mengawasi anak saat belajar di rumah.

Berdasarkan upaya yang dilakukan guru kelas $\mathrm{VI}$ sejalan dengan pendapat Handayani (2020: 115) yang menyatakan bahwa kegiatan pendampingan belajar siswa di rumah memberikan dampak positif baik bagi siswa, guru, maupun orang tua. Orang tua merasa terbantu dengan adanya kegiatan pendampingan belajar ini karena kegiatan ini membuat siswa menjadi lebih paham dengan materi yang diajarkan oleh guru. Selain itu, kegiatan pendampingan belajar ini juga meringankan tugas orang tua dalam membimbing belajar anaknya di rumah.

\section{SIMPULAN}

Implementasi model pembelajaran blended learning untuk meningkatkan kemandirian belajar pada tema menuju masyarakat sejahtera siswa kelas VI SD Negeri 1 Kemujan pada era Covid-19 secara keseluruhan telah dilaksankan dengan baik. Perencanaan pembelajaran yang disusun meliputi pembuatan jadwal pembelajaran, menyusun RPP blended learning, menyiapkan bahan/media/sumber belajar tatap muka dan daring, dan penerapan protokol kesehatan Covid-19 saat pembelajaran tatap muka. Pelaksanaan pembelajaran blended learning yang sudah guru lakukan secara konsisten adalah seeking of information dan acquisition of information, sedangkan pada langkah synthesizing of knowledge dapat dikatakan cukup dalam pelaksanaan pembelajaran karena guru masih menyesuikan pada keadaan siswa, kondisi yang masih dalam pandemi, dan waktu. Pada evaluasi pembelajaran model blended learning telah membuat siswa memiliki kemandirian belajar yang baik seperti siswa sudah memiliki inisiatif belajar mandiri untuk mendalami materi yang diberikan oleh guru, memiliki sikap tanggung jawab dalam mengerjakan tugas, mengatur segala pekerjaan dengan disiplin dalam hal menaati peraturan yang ada di sekolah, memiliki rasa percaya diri dalam hal bersemangat mengikuti diskusi dan percaya diri dalam menyampaikan pendapat, dan memiliki motivasi untuk mencapai tujuan dalam hal memiliki keinginan untuk mendapatkan hasil belajar yang baik.

Kendala dalam mengimplementasikan model pembelajaran blended learning untuk meningkatkan kemandirian belajar yaitu terbatasnya perangkat pembelajaran siswa yang tidak dapat mendukung pembelajaran online, terbatasnya kuota dan jaringan internet saat pengumpulan tugas, keterbatasan orang tua dalam mendampingi anak saat belajar dari rumah. Upaya yang dilakukan untuk mengatasi 
kendala tersebut yaitu penggunaan media pembelajaran online yang mudah dan disesuaikan dengan perangkat pembelajaran yang dimiliki siswa, pengumpulan tugas yang dapat dikumpulkan secara langsung di sekolah, bekerja sama dengan orang tua dalam mendampingi dan mengawasi anak saat belajar di rumah.

Hasil penelitian ini dapat dijadikan dasar untuk penelitian yang serupa dengan implementasi model pembelajaran blended learning untuk meningkatkan kemandirian belajar siswa pada era Covid-19. Guru sebagai pelaksana pembelajaran blended learning dapat mengevaluasi dan mengembangkan pemahaman mengenai pembelajaran blended learning. Siswa sebagai pelaksana pembelajaran blended learning dapat mengembangkan kemandirian belajar yang lebih baik melalui model pembelajaran blended learning.

\section{DAFTAR PUSTAKA}

Budiyono, F. (2020). Implementasi Blended Learning di Masa Pandemi Covid-19. Prosiding Diskusi Daring Tematik Nasional,1(1), 9-11.

Dewi, W. A. F. (2020). Dampak Covid-19 terhadap Implementasi Pembelajaran Daring di Sekolah Dasar. Edukatif: Jurnal IImu Pendidikan, 2(1), 55-61..

Hamka, D. \& Vilmala, B.K. (2019). Pengembangan Perangkat Pembelajaran Blended learning Melalui Aplikasi Google Classroom Untuk Peningkatan Kemandirian Belajar Mahasiswa. Journal of Education Informatic Technology and Science (JelTS), 1(2), 145-154.

Han, X., Wang, Y., \& Jiang, Y. (2019). Towards a Framework for an Institution-Wide Quantitative Assessment of Teachers' Online Participation in Blended learning Implementation. Jurnal International Education, 42 (1), 1-12.

Handayani, T., Khasanah, H.N.,\& Yosintha, R. (2020). Pendampingan Belajar di Rumah Bagi Siswa Sekolah Dasar Terdampak COVID-19. Jurnal Pengabdian Kepada Masyarakat, 1(1), 107.

Husamah. (2014). Pembelajaran Bauran (Blended Learning). Jakarta: Prestasi Pustaka.

Indriani, T.M., Fathoni, T., \& Riyana, C. (2018). Implementasi Blended learning dalam Program Pendidikan Jarak Jauh pada Jenjang Pendidikan Menengah Kejuruan. Jurnal Edutcehnologia, 2(2), 130-139.

Kusumaningrum, B., Kuncoro, K.S., Arigiyati, T.A., \& Trisniawati. (2020) Pendampingan Orangtua Dalam Pembelajaran Daring di Sekolah Dasar: Evaluasi Pembelajaran Daring Selama Masa Pandemi Covid-19. Jurnal Pendidikan Guru Sekolah Dasar, 4 (2) 144.

Menteri Pendidikan dan Kebudayaan No.14 Tahun 2019 Tentang Penyederhanaan Rencana Pelaksanaan Pembelajaran.

Menteri Pendidikan dan Kebudayaan. (2020). SE No 4 Tahun 2020 tentang Pelaksanaan Kebijakan Pendidikan dalam Masa Darurat Penyebaran Covid-19

Peraturan Menteri No 01/Kb/2020 tentang Panduan Penyelenggaraan Pembelajaran Pada Tahun Ajaran 2020/2021 dan Tahun Akademik 2020/2021 di Masa Pandemi (Covid-19).

Undang-undang No 20 Tahun 2003 tentang Sistem Pendidikan Nasional.

Yuliati, Y dan Saputra, D.S. (2020). Membangun Kemandirian Belajar Mahasiswa Melalui Blended learning di Masa Pandemi Covid. Jurnal Elementaria Edukasia, $3(1), 144$. 